\title{
КОНТРАДИКТОРНОСТЬ ОТДЕЛЬНЫХ ПОЛНОМОЧИЙ ФЕДЕРАЛЬНОГО КАЗНАЧЕЙСТВА
}

\author{
(C) 2018 Подкопаева Екатерина Вячеславовна \\ аспирант, кафедра государственных и муниципальных финансов \\ Санкт-Петербургский государственный экономический университет \\ Россия, 191023, Санкт-Петербург, ул. Садовая, д. 21 \\ E-mail: podkopaeva2006@rambler.ru
}

Статья посвящена рассмотрению вопроса взаимозависимости деятельности Федерального казначейства в рамках полномочий по последующему внутреннему государственному финансовому контролю и полномочий по ведению централизованной бухгалтерии потенциальных объектов проверок. Проанализированы полномочия Федерального казначейства в рамках последующего внутреннего государственного финансового контроля во взаимосвязи с полномочиями по предварительному внутреннему государственному финансовому контролю, а также с полномочиями по ведению бюджетного учета и формированию бюджетной отчетности казенных учреждений. Представлена авторская позиция в отношении оптимизации структуры органов власти, осуществляющих функции внутреннего государственного финансового контроля.

Ключевые слова: внутренний государственный финансовый контроль, Федеральное казначейство, цзентрализованная бухгалтерия, антистимулы, централизованная бухгалтерия, предварительный финансовый контроль, последующий финансовый контроль.

На современном этапе развития государственного финансового контроля в России одной из наиболее значимых проблем остается отсутствие генеральной линии в практическом формировании органов власти, осуществляющих полномочия по внутреннему государственному финансовому контролю (далее - ВГФК).

В 2016 году произошло значимое событие, которое стало очередной реперной точкой в процессе развития отечественного ВГФК: упразднение Федеральной службы финансово-бюджетного надзора и передача контрольно-надзорных функций в финансово-бюджетной сфере последней Федеральному казначейству [1].

До 2016 года Федеральное казначейство в рамках функции ВГФК осуществляло предварительный финансовый контроль. Таким образом, после передачи Федеральному казначейству функций последующего финансового контроля в рамках ВГФК произошло объединение в одном органе государственной власти федерального уровня функций предварительного и последующего финансового контроля.

На первый взгляд такое переструктурирование вполне оправдано, поскольку объединяет пул специалистов определенного направления деятельности и поддерживает целостность информационного поля о состоянии финансовой дисциплины в финансово-бюджетной сфере.
Однако такое объединение функций по предварительному и последующему финансовому контролю в рамках ВГФК носит скрытый характер внутренних противоречий.

В соответствии с полномочиями, закрепленными Бюджетным кодексом РФ Федеральное казначейство осуществляет санкционирование операций со средствами федерального бюджета [2]. С этой целью орган Федерального казначейства в рамках предварительного финансового контроля осуществляет проверку документов, представленных организациями. При этом в рамках последующего финансового контроля этот же орган Федерального казначейства осуществляет проверку тех же документов на предмет законности проведенных финансовых операций. То есть, один и тот же орган государственной власти вначале осуществляет определенные действия, предусмотренные в рамках предварительного ВГФК, а затем в рамках последующего ВГФК проводит «самоконтроль» в отношении этих действий.

Таким образом, последующий финансовый контроль в рамках ВГФК, организуемый органом Федерального Казначейства носит характер переконтроля или внутреннего финансового контроля.

При этом, при выявлении последующим финансовым контролем незаконности какой-либо 
финансовой операции объекта проверки, деятельность самого органа Федерального казначейства по предварительному финансовому контролю должна быть автоматически признана неэффективной, поскольку ранее в рамках предварительного финансового контроля такая финансовая операция была санкционирована этим органом.

Следовательно, в деятельности органа ВГФК присутствуют антистимулы эффективной деятельности, то есть выявление определенного вида нарушений у объекта проверки будут свидетельствовать о нарушениях в деятельности самого органа ВГФК.

Более того, в настоящее время начался процесс передачи Федеральному казначейству полномочий по ведению бюджетного учета и составлению бюджетной отчетности казенных учреждений - органов государственной власти, то есть формирование централизованной бухгалтерии на базе Федерального казначейства.

Пилотным проектом в этом направлении в начале 2018 года стала передача Федеральному казначейству полномочий по ведению бюджетного учета и формированию бюджетной отчетности, начислению и оплате труда, иных выплат и связанных с ними обязательных платежей в бюджеты Федеральной службы по аккредитации и ее территориальных органов [3].

Согласно «Дорожным картам» до конца 2018 года аналогичные полномочия должны перейти к Федеральному казначейству Министерства науки и общего образования РФ, Министерства просвещения РФ, в начале 2019 года - Минфина РФ, Министерства строительства и ЖКФ РФ, Федеральной службы по регулированию алкогольного рынка, в первом полугодии 2019 года Федеральной службы по труду и занятости, Министерства РФ по развитию Дальнего Востока и Росимущества [3].

Безусловно, централизация непрофильных функций органов государственной власти таких, как бухгалтерская, юридическая, кадровая, ИТ-функция и т.д. позволяет решить сразу две основные задачи, поставленные перед Правительством РФ - оптимизация численности сотрудников органов государственной власти, которая, в свою очередь, должна привести к сокращению бюджетных расходов.

Вместе с тем, при осуществлении органом Федерального казначейства полномочий по бюджетному учету и формированию бюджетной отчетности казенных учреждений, к которым отнесены органы государственной власти, он будет осуществлять также внутренний финансовый контроль таких казенных учреждений в качестве соответствующего подразделения финансовых функций, в том числе проверку правильности составления бюджетных смет, начисления заработной платы, уплаты обязательных платежей и т.д.

В этом контексте внутренний конфликт интересов органа государственной власти приобретает масштабы конфликта интересов в рамках всего последующего ВГФК, поскольку нарушения выявленные в рамках последующего ВГФК у объекта проверки будут свидетельствовать, как о нарушениях в самой системе Федерального казначейства, так и в системе ВГФК в целом. Не говоря уже о парадоксальности привлечения к ответственности (например, административной) должностных лиц Федерального казначейства, осуществляющих ведение бюджетного учета и формирование бюджетной отчетности проверяемого объекта, лицами Федерального казначейства осуществляющими последующий ВГФК.

При этом показатели деятельности Федерального казначейства в целом как органа государственной власти будут снижаться по мере повышения результативности ВГФК.

Таким образом, в процессе решения многокритериальной задачи обеспечения соблюдения бюджетного законодательства, концентрация полномочий по предварительному ВГФК, ведению бюджетного учета/ формированию бюджетной отчетности потенциальных объектов контроля и последующего ВГФК в одном органе государственной власти видится чрезмерной, способствующей формированию элементов формализма в контрольно-надзорной деятельности в рамках ВГФК.

С учетом изложенного, во избежание развития негативных последствий такого агрегирования дискреционных полномочий в одном органе государственной власти видится целесообразным обособление контрольно-надзорных функций в рамках последующего ВГФК от деятельности органа, осуществляющего функции, которые способствуют возникновению антистимулов при проведении проверок.

Как показывает международный опыт, независимость ВГФК обеспечивается, помимо прочего, автономностью контрольно-надзор- 
ных мероприятий, осуществляемых специально созданными для этих целей органами государственной власти (Франция - Генеральная инспекция финансов [4], Индия - Офис контролера счетов [5], Финляндия - Группа по аудиту [6], Нидерланды - Центральная аудиторская служба [7] и др.). Как правило, такой орган государственной власти находится в непосредственном подчинении Министерства финансов страны.

Такой подход при формировании системы органов ВГФК обеспечивает нивелирование внутренних противоречий, вызываемых конфликтом интересов при осуществлении последующего ВГФК, посредством обособления функции последующего ВГФК от иных функций, осуществление которых способно повлиять на объективность результатов проверочных мероприятий и, соответственно, на качество и эффективность ВГФК в целом.

\section{Библиографический список}

1. Указ Президента Российской Федерации от 02 февраля 2016 года № 41 «О некоторых вопросах государственного контроля и надзора в финансово-бюджетной сфере» - [Электронный ресурс] - Режим доступа: http://base.consultant.ru.

2. Постановление Правительства РФ от 01.12.2004 N703 «О Федеральном казначействе» - [Электронный ресурс] - Режим доступа: http://base.consultant.ru.

3. Официальный сайт Федерального казначейства - [Электронный ресурс] - Режим доступа: http://www. roskazna.ru/dokumenty/tsentralizovannyy-byudzhetnyy-uchet-i-otchetnost/eksperiment-po-peredachepolnomochiy-po-vedeniyu-byudzhetnogo-ucheta-i-formirovaniyu-byudzhetnoy-otch/

4. Официальный сайт Генеральной инспекции финансов Франции - [Электронный ресурc] - URL: http://www. igf.finances.gouv.fr/cms/sites/igf/accueil/decouvrir-ligf/le-statut-et-lhistoire-de-ligf/les-textes-de-reference. html

5. Официальный сайт Министерства финансов Индии - [Электронный ресурс] - URL: https://dea.gov.in/

6. Официальный сайт Министерства финансов Финляндии - [Электронный ресурc] - URL: https://vm.fi/en/ departments

7. Официальный сайт Правительства Нидерландов - [Электронный ресурс] - URL: https://www.rijksoverheid. $\mathrm{nl} /$ ministeries 